\title{
HUBUNGAN POLA KONSUMSI ZAT BESI DENGAN KADAR HEMOGLOBIN PADA IBU HAMIL DI BPS KABUPATEN PRINGSEWU LAMPUNG TAHUN 2015
}

\section{Sumi Anggraeni}

${ }^{1}$ Kebidanan, STIKes Muhammadiyah Pringsewu Lampung, affan.ummi@gmail.com

\begin{tabular}{l} 
INFO ARTIKEL \\
\hline RiwayatArtikel: \\
Diterima: 06-01-2018 \\
Disetujui: $31-01-2018$ \\
\hline
\end{tabular}

\section{Kata Kunci:}

Pola konsumsi,

Zat Besi, Hemoglobin, Anemia

\begin{abstract}
ABSTRAK
Abstrak: Hasil kajian beberapa penelitian, perdarahan pada ibu hamil dan persalinan merupakan komplikasi dari anemia selama kehamilan. Penyebab anemia menurut WHO tahun 2012 adalah defisiensi besi, kurangnya asam folat, defisiensi vitamin B12, infeksi dan penyakit keturunan. Anemia karena defisiensi besi merupakan penyebab utama dari anemia. anemia defisiensi besi dapat dilihat dari kadar hemoglobin dan kadar feritin yang rendah. Rendahnya hemoglobin disebabkan oleh pola konsumsi dan kepatuhan minum zat besi, terutama di negara berkembang. Tujuan dari penelitian ini adalah mengetahui hubungan pola konsumsi zat besi dengan kadar hemoglobin pada ibu hamil di BPS Pringsewu Lampung tahun 2015. Desain penelitian menggunakan analitik observational dengan pendekatan crossectional. Sampel dalam penelitian ini adalah ibu hamil dengan usia 32 minggu yang berjumlah 108 orang, dan alat ukur menggunakan kuesioner wawancara dan hemoglobin rapid test. Hasil penelitian diperoleh tidak ada hubungan pola konsumsi zat besi dengan kadar hemoglobin pada ibu hamil $(p=0,323)$.
\end{abstract}

\begin{abstract}
A$ review of several studies, bleeding during pregnancy and childbirth is a complication of the anemia during pregnancy. The cause of anemia according to the WHO in 2012 is iron deficiency, lack of folic acid, vitamin B12 deficiency, infectious and hereditary diseases. Iron deficiency anemia is a major cause of anemia. Iron deficiency anemia can be seen in the levels of hemoglobin and ferritin levels are low. Low hemoglobin caused by consumption patterns and adherence to iron, especially in developing countries. The purpose of this study was to determined the relationship of consumtion patterns of iron with hemoglobin levels in pregnant women in BPS Pringsewu Lampung 2015. This research design using analytical observational with cross-sectional approach. The sample in this study were pregnant women aged 32 weeks, amounting to 108 people, and measuring devices used questionnaires and interviews hemoglobin rapid test. The results obtained no relationship consumtion patterns of iron with hemoglobin levels in pregnant women $(p=0.323)$
\end{abstract}




\section{A. LATAR BELAKANG}

Kematian Ibu masih menjadi masalah kesehatan masyarakat di Indonesia. Berdasarkan data Survei Demografi Kesehatan Indonesia (SDKI) Angka Kematian Ibu (AKI) di Indonesia meningkat yaitu 359 per 100.00o kelahiran hidup pada tahun 2012. Data ini menunjukkan peningkatan dibanding tahun 2007 yaitu 124 per $100.000^{1}$.

Penyebab kematian ibu secara global 80\% yang disebabkan kematian langsung yaitu akibat komplikasi kehamilan, persalinan dan masa nifas ${ }^{2}$. Komplikasi-komplikasi yang menyebabkan kematian ibu antara lain perdarahan $54,2 \%$. Sebab lain, yaitu infeksi $27,2 \%$ dan gestosis $18,6 \% 3$. Perdarahan menduduki peringkat pertama dengan menyumbang 54,2\% kejadian untuk meningkatkan AKI 3.

Hasil kajian beberapa penelitian, perdarahan pada ibu hamil dan bersalinan merupakan komplikasi dari oleh anemia selama kehamilan. Penyebab anemia pada kehamilan menurut WHO tahun 2012 adalah defisiensi besi, kurangnya asam folat, defisiensi vitamin B12, infeksi dan penyakit keturunan. Anemia karena defisiensi besi merupakan penyebab utama dari kejadian anemia. anemia defisiensi besi dapat dilihat dari kadar hemoglobin dan kadar feritin yang rendah. Rendahnya hemoglobin disebabkan oleh pola diet yang buruk, terutama di negara berkembang 4 .

Prevalensi Anemia sendiri masih menjadi permasalahan dunia dan negara berkembang. Tingginya prevalensi anemia di dunia terlihat dari hasil kajian WHO tahun 2005 sebesar 41,8\% yang dikategorikan sebagai masalah penting dalam kesehatan 4,5. Di Indonesia prevalensi Anemia tahun 2012 menunjukkan 37,1\% yang masih berada dalam kategori permasalahan kesehatan sedang 6 .

Selama ini WHO mengeluarkan kebijakan untuk mencegah anemia kehamilan dengan memberikan supplement pada ibu hamil, fortifikasi besi pada makanan, dan pendidikan kesehatan tentang nutrisi dan gaya hidup ibu hamil 4,5 . Di negara berkembang ibu hamil wajib mendapat tambahan supplement besi selama kehamilan. Hal tersebut didukung oleh pemerintah Indonesia dengan mengeluarkan Peraturan Pemerintah NOMOR 1457/MENKES/SK/X/2003 bahwa ibu hamil diwajibkan konsumsi zat besi setiap hari selama 90 hari kehamilan.

Pemberian zat besi setiap hari merupakan standar dari program pemerintah dan WHO untuk mencegah anemia. Namun pemberian zat besi setiap hari ini memiliki banyak kekurangan terutama terhadap kepatuhan ibu konsumsi zat besi. Penyebab utama rendahnya kepatuhan konsumsi zat besi adalah efek samping setelah konsumsi zat besi berupa mual, konstipasi, feses yang hitam dan rasa besi yang tidak enak 7 .
Pencegahan efek samping dari mengkonsumsi zat besi setiap hari dapat dilakukan dengan memahami pola pergantian sel intestinal dalam darah yang dilakukan setiap 5-6 hari. Oleh sebab itu beberapa kajian studi menyebutkan bahwa ibu hamil tidak perlu konsumsi zat besi setiap hari. Tujuan dari pola ini adalah untuk mengurangi kejadian efek samping setelah konsumsi zat besi. Selain itu kadar hemoglobin diatas $13 \mathrm{gr} / \mathrm{L}$ berhubungan negatif terhadap kejadian premature dan Bayi Berat Lahir Rendah (BBLR) 4.

Menurut Souza tahun 2009 zat besi oral dapat diberikan sebanyak sekali seminggu dan dua atau tiga kali perminggu dengan hasil tidak ada perbedaan kadar hemoglobin dengan ibu yang konsumsi zat besi setiap hari ${ }^{8}$. Hasil tersebut sesuai dengan penelitian Hanieh Dkk tahun 2013 bahwa ibu yang konsumsi zat besi seminggu 2 kali dengan setiap hari, tidak memiliki perbedaan kadar hemoglobinnya pada usia 32 minggu kehamilan 9.

Kedua penelitian diatas di didukung oleh rekomendasi WHO pada tahun 2011 bahwa ibu hamil yang tidak anemia, boleh mekonsumsi zat besi secara interval asalkan kondisi wilayahnya berada dalam prevalensi anemia <20\%. Berdasarkan profil kesehatan kabupaten Pringsewu prevalensi anemia di kabupaten Pringsewu hanya sebesar 0,5\% dan kasus BBLR 21,3\% di tahun 2014. Data ini menunjukkan bahwa prevalensi anemia di Kabupaten Pringsewu jauh lebih rendah dibandingkan dengan prevalensi anemia di provinsi Lampung tahun 2007 sebesar 69,7\%.

Hasil pra survey dari beberapa bidan di kabupaten Pringsewu bahwa tidak semua bidan meresepkan zat besi setiap hari tapi ada juga yang meresepkan zat besi secara berkala bagi ibu hamil yang mudah mual dalam kehamilannya. Namun belum ada evaluasi dari pola pemberian zat besi pada ibu hamil di kabupaten Pringsewu

Berdasarkan kajian dalam chochrane review tahun 2012 bahwa ibu hamil yang mengkonsumsi zat besi secara berkala lebih sedikit mengalami gejala efek samping karena konsumsi zat besi. Namun masih sedikitnya bukti bahwa ibu hamil yang konsumsi zat besi secara berkala di negara berkembang memiliki kadar hemoglobin yang sama dengan ibu hamil yang konsumsi zat besi setiap hari ${ }^{10}$.

Berdasarkan latar belakang di atas maka peneliti tertarik untuk mengetahui hubungan pola konsumsi zat besi dengan kadar hemoglobin ibu hamil di BPS Kabupaten Pringsewu Lampung.

\section{B. METODE PENELITIAN}

Desain penelitian ini menggunakan analitik observational dengan pendekatan crossectional. Sampel dalam penelitian ini adalah ibu hamil dengan usia 32 minggu yang berjumlah 108 orang, dan alat ukur menggunakan kuesioner wawancara dan hemoglobin rapid test. 


\section{HASIL PENELITIAN}

\section{Analisis Univariat}

Analisis Univariat dilakukan terhadap tiap variabel penelitian. Pada analisis ini akan menghasilkan distribusi frekuensi pada variabel pola minum dan rata-rata pada variabel hemoglobin dan disajikan dalam bentuk tabel dan teks

\section{TABEL 1}

Distribusi pola minum zat besi di Bidan Praktik Swasta Pringsewu Tahun 2015

\begin{tabular}{lcc}
\hline \multicolumn{1}{c}{ Pola Minum } & Frekuensi & Persentase \\
\hline 1 x/minggu & 16 & 14,8 \\
2-3 x/minggu & 48 & 44,4 \\
Setiap hari & 44 & 40,7 \\
\hline Total & $\mathbf{1 0 8}$ & $\mathbf{1 0 8}$
\end{tabular}

Berdasarkan Tabel 1, diketahui bahwa kurang dari sebagian adalah memiliki pola minum 2$3 x /$ minggu (44,4\%) dan setiap hari $(40,7 \%)$, sedangkan sisanya memiliki pola minum 1 $\mathrm{x} /$ minggu (14,8\%).

TABEL 2

Rata-Rata Kadar hemoglobin dan Distribusi Frekuensi Anemia di Bidan Praktik Swasta Pringsewu Tahun 2015

\begin{tabular}{llll}
\hline Kondisi Hemoglobin & $\begin{array}{c}\text { Mean } \pm \text { SD } \\
\mathbf{g} / \mathbf{d l}\end{array}$ & $\mathbf{N}$ & $\mathbf{\%}$ \\
\hline Kadar Hemoglobin & $10,86 \pm 0,94$ & & \\
Range & 4,90 & 60 & 55,6 \\
Normal & & 48 & 44,4 \\
Anemia & & $\mathbf{1 0 8}$ & $\mathbf{1 0 0}$
\end{tabular}

Berdasarkan Tabel 4.3, diketahui bahwa rata-rata kadar hemoglobin ibu hamil 10,86 g/dl dengan standar deviasi $0,94 \mathrm{~g} / \mathrm{dl}$. mesikipun lebih dari setengah dalam keadaan normal $(55,6 \%$ \%) namun ibu hamil yang mengalami anemia sebesar (44\%).

\section{Analisis Bivariat}

Analisa ini digunakan untuk melihat hubungan pola minum zat besi dengan kadar hemoglobin pada ibu hamil di BPS Pringsewu, maka dilakukan analisis uji One Way Anova dengan $\mathrm{Cl}$ 95\% dan a $=0,05$ dapat dilihat pada tabel berikut

\section{TABEL 3}

Distribusi rata-rata kadar hemoglobin menurut pola konsumsi tablet besi di Bidan Praktik Swasta

\begin{tabular}{cccc}
\multicolumn{4}{c}{ Pringsewu Tahun 2015} \\
\hline Variabel & $\begin{array}{c}\text { Mean } \pm \text { SD } \\
\text { g/dl }\end{array}$ & $\mathbf{9 5 \%}$ CI & $\boldsymbol{\rho}$ \\
\hline 1x/minggu & $10,63 \pm 1,02$ & $10,08-11,17$ & 0,323 \\
$2-3$ x/minggu & $10,79 \pm 0,87$ & $10,54-11,05$ & \\
Setiap hari & $11,01 \pm 0,97$ & $10,71-11,30$ & \\
\hline
\end{tabular}

Rata-rata kadar hemoglobin pada ibu hamil dengan pola minum zat besi $1 \mathrm{x} / \mathrm{minggu}$ adalah 10,63 g/dl dengan standar deviasi 1,02 g/dl. Pada ibu hamil yang mengkonsumsi zat besi 2-3 $\mathrm{x} /$ minggu, rata-rata hemoglobinnya adalah 10,79 $\mathrm{g} / \mathrm{dl}$ dengan standar deviasi $0,87 \mathrm{~g} / \mathrm{dl}$. Pada ibu hamil yang mengkonsumsi zat besi setiap hari, rata-rata hemoglobinnya adalah $11,1 \mathrm{~g} / \mathrm{dl}$ dengan standar deviasi $0,97 \mathrm{~g} / \mathrm{dl}$. Hasil uji statistik didapatkan nilai $\rho=0,323$, berati pada $\alpha=5 \%$ tidak ada perbedaan kadar hemoglobin antara ketiga kelompok yang berbeda signifikan. Maka hipotesis alternatif ditolak dan hipotesis nul diterima. Berdasarkan hal diatas maka dapat disimpulkan bahwa tidak ada hubungan pola konsumsi zat besi dengan kadar hemoglobin pada ibu hamil di BPS Kabupaten Pringsewu.

\section{PEMBAHASAN}

Setelah dilakukan analisis dan interpretasi data mengenai hubungan pola konsumsi zat besi dengan kadar hemoglobin pada ibu hamil di BPS Kabupaten Pringsewu, maka diketahui sebagai berikut:

Hasil penelitian ditemukan tidak adanya hubungan antara pola konsumsi zat besi dengan kadar hemoglobin pada ibu hamil di BPS Kabupaten Pringsewu, dimana nilai $\mathrm{p}$ value $=0,323$ yang berarti hipotesis (Ho) diterima artinya pola konsumsi zat besi dengan kadar hemoglobin pada ibu hamil di BPS Kabupaten Pringsewu.

Berdasarkan hasil di atas dapat diketahui bahwa pola minum bukan merupakan faktor determinan yang berpengaruh terhadap terjadinya kejadian perdarahan di luar siklus haid.

Sejalan hasil Cochran review pada beberapa penelitian yang didapatkan bahwa ibu hamil yang mengkonsumsi tablet besi setiap dengan pola intermittet tidak terapat perbedaan kadar hemoglobinnya. Hal ini berdasarkan hasil kajian tori bahwa sel intestinal di dalam usus terjadi pergantian zat besi setiap 6 hari.

Meskipun tidak terdapat perbedaan pola konsumsi zat besi dengan kadar hemoglobin ibu hamil. Prevalensi anemia di BPS Kabupaten Pringsewu tergolong tinggi yaitu 44\%. Hal ini jauh lebih tinggi bila dibandingkan data Kabupaten Pringsewu yaitu $0,5 \%$, dan data prevalensi anemia nasional yaitu $37,1 \%$.

Tingginya perbedaan hasil pemeriksaan dalam penelitian ini dan data Kabupaten Pringsewu menjadi issu tersendiri bahwa alat pemeriksaan kadar hemoglobin masih perlu dipertanyakan atau sistim penelitian yang tepat masih perlu dirancang. Hal ini sebagai masukan bahwa perlunya alat diagnostic yang tepat guna penatalaksaan yang optimal sehinggap permasalahan anemia dapat teratasi. 


\section{E. SIMPULAN DAN SARAN}

Berdasarkan analisis hasil penelitian didapatkan bahwa tidak ada hubungan pola konsumsi zat besi dengan kadar hemoglobin pada ibu hamil di BPS Kabupaten Pringsewu. Dengan demikian maka bidan perlu mengatasi masalah anemia tidak hanya dari konsumsi tablet besi saja, melainkan mempertimbangkan faktor lain yang berhubungan dengan kadar hemoglobin

\section{UCAPAN TERIMA KASIH}

Tim penulis mengucapkan terima kasih kepada LPPM UM mataram yang telah mempublish penelitian ini.

\section{DAFTAR PUSTAKA}

1. SDKI. Indonesia Demographic Health Survey. Jakarta: Kementrian Kesehatan RI2012.

2. Winkjosatro H. Ilmu Kebidanan. Jakarta: Yayasan Bina Pustaka; 2009.

3. Manuaba IGB. Ilmu Kebidanan, Penyakit Kandungan dan Keluarga Berencana. Jakarta: EGC; 2010.

4. WHO. Intermittent Iron and Folic Acid Supplementation in Non-Anemic Pregnant women. In: Organization WH, editor. Geneva2012.

5. WHO. Daily Iron and Folic Acid Supplement in pregnant Women. In: Organization WH, editor. Geneva2012.

6. Riskesdas. Riset Kesehatan Dasar. Jakarta: Kementrian Kesehatan RI2013.

7. Bilimale A, Anjum J, Sangolli HN, Mallapur M. Improving Adherence to Oral Iron Supplementation During Pregnancy. Australian Medical Journal. 2010;3(5):10.

8. Souza AID, Filho MB, Bresani CC, Ferreira LOC, Figueiroa JN. Adherence and Side Effect of three ferrous sulfate treatment regiment on anemic pregnant woment in clinical trials. Cad sude publica. 2009;25(6):9.

9. Hanieh S, Ha TT, Simpson JA, Casey GJ, Khuong NC, Thoang DD. The Effect of Intermeittent Antenatal Iron Supplementation on Maternal and Infant Outcomes in Rural Viet Nam: A Cluster Randomised Trial. PlosMedicine. 2013;10(6):15.

10. Peña JP, Regil DLM, Dowswell T, Viteri FE. Intermittent oral iron supplementation during pregnancy (Review). The Cochrane Library. 2012(7):230.
PROFIL PENULIS UTAMA

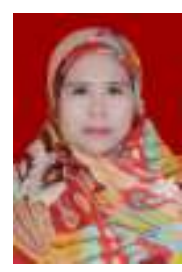

Sumi Anggraeni, lahir di Sukoharjo IV, 04 Juni 1981. Pendidikan D3 kebidanan Poltekkes Tanjungkarang, D4 Kebidanan UNPAD, S2 kebidanan UNPAD. 